\title{
Killing the Field of Dreams: George W. Bush, Empire and the Politics of Misrecogtion
}

\author{
Jeremy Varon
}

Robin Palmer and his crew of neophyte Weathermen were set for action. The plan was to firebomb afterhours six locations in New York City — a bank and two police stations among them-on December 1, 1970, a year to the day that Chicago police and the FBI murdered Black Panther leader Fred Hampton as he lay in his bed. The anniversary assault would both avenge Hampton's killing, which had catalyzed Weatherman's move underground, and amplify the budding "armed struggle" of white American radicals.

There was, however, the matter of Steve Weiner. Palmer had some experience with infiltrators. Sam Melville, the leader of an independent New York City bombing collective and Palmer's best friend, had been busted months earlier when he recruited undercover FBI agent George Demerle, known in radical circles for his brash talk of violence, to help him blow up military trucks. The sting landed Melville a fourteen-year prison sentence, cut short when he was fatally shot by a New York State trooper in the 1971 Attica uprising, and took down several others, but had narrowly missed Palmer.

Weiner lacked the crazed swagger of the provocateur Demerle, but still left Palmer uncomfortable. To assuage his doubt, Palmer got Weiner stoned and conducted a halfhearted interrogation — a technique Palmer later deemed "superficial by Weatherman standards." [1] Just shy of reassured, Palmer nonetheless apologized to Weiner for the embarrassing ritual. The last shudders of caution were stilled when Weiner suggested that the two patch things up by taking in a Mets game. "No Mets fan," Palmer comforted himself, "would be so unsportsmanlike as to infiltrate a group."

Palmer was captured en flagrant with petrol bombs destined for the First National Bank. He soon entered Attica prison where he joined Melville, who would die in his arms. Weiner had been sent straight from the FBI academy into undercover operations against radicals.

Weiner's offer of a Mets game stuck with Palmer for decades and stuck with me through my years of research in the 1990s on the Weather Underground. Immersed as I was through endless reading and interviews in the shocks of the late 1960s, it was comforting to know that there was still room-in between the Vietnam war and the war to end it, the assassinations, the rallies, riots, busts, and all the shouting and tears and blood and worry-for something so familiar, permanent, and seemingly incorruptible as baseball. It was the Mets no less, the lovable losers turned "Amazin's" on their World Series run in the summer of "69_ a fairy-tale drama on the side of hope and togetherness, like the lunar landing or even Woodstock.

Baseball had substantial pedigree as a palliative for hard and scary times. The late, muckraking journalist Jack Newfield confessed that he might have gone crazy in the 1960s and early 1970s if not for his enduring belief in the existence of two Americas. One was the ugly America of the Vietnam War and Watergate, of bigotry and deceit. But there was another, truer, better America, epitomized for him by roots music like black gospel and by baseball. Baseball had never been fully pure, as Newfield, witness to Jackie Robinson's struggle, knew so well. But it had managed to stay just ahead of the times on issues like race, to rise above periodic division and strife, and to dig below the pocked 
surfaces of cynicism and doubt to some deep American spring of faith in the power of possibility, renewal, and fair play. In light of these associations, familiar to anyone in baseball's grand church, Palmer's reassurance at the offer of a ballgame made perfect sense to me, as did his sense of betrayal. A "Mets' fan". . the scoundrel!

More than thirty years later, baseball again did valuable service to the cause of healing and hope. The Mets, by reputation still the gritty, blue-collar alternative to their perennially dominant cross-town rival, paid ceaseless tribute to fallen firemen and police officers. The Yankees, for all the soulless preppie power of their arch-capitalist owner, put a wounded city on their backs, nearly carrying it with late-inning heroics in the fall of 2001 to the fleeting heaven of champions. The pain of the game seven World Series loss seemed drowned in fans' gratitude for the wild ride; a stadium sign played tricks on time and memory in its sweet plea to relish the moment: "These are the good old days." The ominous quality of the Series' metaphor - that superior wealth and firepower do not guarantee victory, that even the mighty Yankee empire has its limits—-had not yet kicked in.

Two years following, with the "liberation" of Afghanistan and Iraq complete and signs of quagmire only just emerging, the Yankees' improbable victory over the Red Sox seemed an affirmation of the order of things: the eternity of New York, empire, and myth (the Curse!), but also the impossibility, within a primordial Calvinist cosmology, of the expiation of sin. The Red Sox's unfathomable victory over the Yankees and World Series title a year later blew open all doors of certainty: reality can overcome myth, nothing-including empires-lasts forever, and anything, indeed, is possible. Whether baseball, in a new era of war and worry, was now more compelling for its distracting drama or its richly ambivalent allegories (and how to choose between "the Evil Empire" and "the Idiots" anyhow?) seemed a matter of taste. All the while, another black man threatened to surpass Babe Ruth's home run total, but this time without the demeanor of a cautious upstart or such intense white backlash. Call it progress.

There was, however, the matter of steroids. For all the epic storylines and shattered records, this has been no golden age for baseball. Rather, it has been the great era of moral rot, caused by the systematic violation for at least two decades of the game's literal and metaphorical essence: fair play. Robin Palmer's story of betrayal, however poignant for its own day, simply could not work any longer, as no one in his or her right mind would now equate baseball with sportsmanship, let alone innocence. Even the recent "good old days" weren't.

Having squandered its status as refuge, baseball has itself become, in part, more refuse-both a symbol and instance of American ugliness. The tenor of our troubled times can be easily read off this tarnished sign. Consider the March 17, 2005 congressional hearings on steroid use. Before a television audience and a crush of media, ghoulish counsels for the Commissioner's Office and Players' Union alike made solemn allusions to a grave problem, but took no responsibility whatsoever for it. Home-run hero Mark McGwire, looking more like a sallow, middle-aged father than Paul Bunyan, insisted that he was "not here to talk about the past" and repeatedly invoked his lawyer's advice that he keep mum about what he might have seen and done. [2] Curt Schilling, invited as the loud-mouthed whistleblower, scrambled on his wrecked ankle back across the thin white line protecting obscenely wealthy cheats and crooks. Grandstanding politicians, claiming no mandate to do anything in particular, balanced maudlin admonitions with fawning praise of the people they were meant to interrogate.

Even the most myopic sports fan could not help but sense that he had seen this all before. He of course had, whether in the fleeting Enron and WorldCom hearings, the grueling 9-11 Commission inquiry, the hearings on preand post-9-11 intelligence failures, or those on torture at Abu Ghraib prison, partially reprised by the confirmation process of Attorney General Alberto Gonzales. Wherever one looked, the tropes of corruption and cowardice were more or less the same. Plausible deniability, blame shifting, and the exculpatory insistence on the value of "moving forward" serve as universal alibis. In the face of tragic messes, caused in part by awful decisions and staggering negligence, the past is somehow not the issue. (Bush had initially resisted the formation of a 9-11 Commission; Condoleezza Rice, who at first refused to testify, thought it best not to dwell on such things as an August 6, 2001 memo titled, "Bin Laden Determined to Attack Inside United States.") No one-or everyone, and hence, no one, as per the claim that all credible sources thought Iraq had WMD—is to blame. Indeed, everyone, in the protective cant of high officialdom, serves "honorably" (excepting zealous truth-tellers like former U.N. inspector Scott Ritter), no matter how disgraceful the actual conduct. And scarcely anyone has to lose his or her job or go to prison, save at the bottom of a mystified chain of command or lucrative pyramid. [3] The "price" for the grandest failures, as in the case of former CIA Director George Tenet, is the award of the Medal of Freedom, the nation's highest civilian honor. Hence, an American era of crime not only without punishment, but with ritual reward and a career ladder that at its lofty rungs allows one to "fail upward." (Consider Rice's promotion to Secretary of State, Paul Wolfowitz's 
appointment as the head of the World Bank, or the ascendance of Gonzales, who as White House counsel advocated that the United States disregard Geneva Convention restrictions on torture.)

The weave between the fractured worlds of baseball, politics, and high finance grows more disturbing as one speculates about the origins of the steroids scandal. How and why, beyond the timeless lure of competitive advantage, did steroid use grow so rampant in the mid-1990s? In the wake of the 1994 strike, attendance was sharply down and fans in near-mutiny. So baseball, according to one hypothesis, bio-fueled its revival by having supersized players launch bombs to cheering crowds. Bigger muscles and smaller ballparks made for more home runs, enhanced drama, heightened demand, fatter contracts, pricier tickets, and bigger revenues. Far from honest dupes, the owners, according to one critic, all but encouraged "the jettisoning of the game's subtlety" in favor of "homerun madness," no matter how achieved. (Bissinger 2005:A35) Within this power and profit-driven logic, baseball has a blacker eye, but also its surest alibi. The fans, getting and paying for what just what they wanted, became complicit in their own deception; they never demanded, after all, that laws and tradition be honored in the giving and found a way to rationalize cartoonishly brawny bodies and garish statistical anomalies. The sports media, itself a cause and beneficiary of baseball's highlight-friendly resurrection, failed to ask the tough questions with sufficient stamina and bite.

Toggle back to politics, and a similar sense of collective shame emerges. After 9-11, much of America demanded of its government only that it be kept safe, imposing neither moral restrictions on how it should be done, nor a rational standard for what makes the country truly safer. What should have sounded great ethical alarms—civilian casualties in Afghanistan equaling the nearly 3,000 lost on 9-11; [4] reports years ago of the "extraordinary rendition" to foreign countries of terror suspects and their likely torture in the CIA's secret, global gulag; [5] the putatively indefinite internment in Guantanamo Bay of many ordinary men, landed there by bribes and vendettas - caused barely a peep. Without the public either explicitly asking for it or, certainly, disavowing it, terror and human rights abuse became standard means for fighting alleged terrorists and human rights abusers.

The story of broad complicity in the Iraq saga is equally sorry. Media belief in the Bush administration's hype of Iraqi WMD was near universal. [6] Even the New York Times, savaged by the right for its anti-Bush posture, admitted to having failed its own journalistic standards and role as watchdog in its faulty reporting on WMD and passive acceptance of administration claims. [7]At its tragic-comic worst, a dumbfounding percentage of the public held onto its belief in a great lie — that of Iraqi involvement in the September 11 attacks — that even the Bush administration was forced to renounce. [8] This life-and-death drama of shared, willful delusion was presaged by the accounting scandals of Enron, Arthur Anderson, et. al. In the "go-go "90s," with stock ownership expanding and profits soaring, corporate America heard thunderous public cries for gleaming annual reports and giddy share values. They heard less often and loudly, perhaps — the demand that it all be done above board. Far from a few bad apples, orchards of the unscrupulous thus conjured virtual profits to adorn all but phony companies. Outrage and subpoenas followed only when key institutions and people-investment banks and legions of pensioners among thembegan losing vats of money.

By having its players juiced, baseball irrevocably cooked its books, such that its vaunted records and the hallowed past they represent no longer make sense. Unlike the criminal forgeries at Enron, the cost is not measured in ruined portfolios, but in the loss of its most precious, if abstract, possession: its integrity. With the loss, baseball takes its place alongside politics and corporate capitalism in forming an era of permanent scandal, never-ending investigation, and inexpugnable asterisks. And who has presided over this recent rotting of the American kingdom? A failed corporate executive, rewarded with ownership of the Texas Rangers' baseball franchise (whose new stadium was first named Enron Field), turned master of lies and delusions. . . of course!.

Baseball provides here a summertime metaphor for a political and cultural condition that could be described by more direct means. The core issues disclosed in the metaphor, however, seem necessary predicates for broaching the broad assignment of this essay: assessing what light Sixties'-era radicalism may shed on popular resistance today. By my judgment, the aching distance between then and now, notwithstanding resurgent activism and the similarities between the Vietnam and Iraq wars, is most apparent; the withered salience of Robin Palmer's invocation of baseball underscores, above all, that distance.

We currently live in an era of the open secret in which mechanisms for stopping political crimes and holding the offenders to account seem to have broken down beyond reckoning or repair. While the 1960s and early 1970s were rife with outrages, this one-defined by the absence of remotely effective outrage at outrageous governmental 
conduct — seems new, certainly in degree and likely in kind; its hold on American public life obviates any simple effort to mine from the past a sense of what is to be done today. The first task is to take closer stock of the affliction, and though limited reference to the past is helpful with this, any grander comparison of then and now will have to wait until outrage again has some consequence.

To indict the Bush administration's roguish conduct and obsession with secrecy, the repentant Nixon aide John Dean (2004) wrote a book titled Worse than Watergate. Indeed, lying one's way into a war by "fixing" intelligence around predetermined agendas dwarfs the Nixon administration's use of dirty tricks against political opponents and attempts to cover it up. [9] Even worse, however, has been the conspicuous immunity with which the Bush presidency has savaged the truth and the public's trust. The offenses comprising Watergate, one may argue, were hardly the worst of the Nixon administration (consider, by comparison, the 1972 mining of North Vietnamese harbors or the U.S.-aided coup in Chile in 1973). Even so, Watergate brought deep shame on Nixon and functioned as at least a partial vindication of the antiwar movement and even the counterculture. (Disgust with Nixon was so pervasive that I recall, as a young boy in 1975, finding it hard to find any adult who would admit to having voted for him in 1972.) Watergate served, moreover, as the watershed for an era in public life, albeit brief and inadequate, of atonement and reconciliation, of institutional reform and the imposition of meaningful checks on state power. [10]

However much an object of half-blind devotion, Bush never enjoyed consensus support for his policies. Just after 9-11, some Americans, and New Yorkers especially, protested that their "grief is not a cry for war" and greeted core aspects of the "war on terror" with the slogan "Not in My Name." Many more were vocal in their view that the administration sought to frighten America into war in Iraq and bully the international community into signing off on it. Every suspicion of administration critics has been confirmed, and then some: that there were no Iraqi weapons of mass destructions; that the administration set up the U.N. inspections to fail in order to enhance its causus belli; that Colin Powell's portentous "case" before the United Nations of Iraqi WMD had no basis in fact; that the White House overrode intelligence doubting the existence of an active Iraqi nuclear weapons program, while Cheney fatuously put the fear of Armageddon into middle America; [11] and that the war's main boosters egregiously miscalculated its human and financial cost.

Former counter-terrorism chief Richard Clarke appeared to seal the damning case by reporting that the Bush administration was shamefully slow-footed in dealing with the demonstrable threat Al Qaeda posed and zealously determined to see some phantom Iraq-9-11 connection as a prelude to a U.S. attack. His response to Secretary Rumsfeld's talk on September 12, 2001, of "getting Iraq" — that it would be akin to "our invading Mexico after the Japanese attacked us at Pearl Harbor"_captured with epic gumption the administration's ludicrous resolve to have its coveted invasion. (Clark 2004:31-32). And then followed the cruelest cut, the release in April 2002 of the Abu Ghraib prison photos and accompanying revelation that the mistreatment of Iraqi detainees had been both extensive and grotesque. A prison complex notorious during Hussein's regime as a place of torture had become notorious, under the U.S. occupation, as a place of torture. With this hard fact, the moral case for Iraq's "liberation" and America's claim of world-saving benevolence had been ruthlessly undercut. [12]

Each revelation brought to Bush's foes a sense of vindication (if vastly more bitter than sweet) and the reasonable expectation that some vital line had at last been crossed: that resignations, dismissals, indictments, or even impeachment proceedings would soon follow, wrapped in a grave sense of constitutional and moral crisis. One could plausibly imagine at the moments of greatest shock that American wrath would turn inward, bringing down its false prophets of security and restored glory in a torrent of public recrimination, and that the country would soon emerge on a vastly different track. Short of that, surely the American people, by all rights indignant at being fooled once, would vote Bush out of office. For those in the anti-Bush camp, continued faith in the basic rationality of the political universe seemed to depend on the playing out of this primitive correlation between truth and consequences. Just to be sure that the equation still held, millions of Americans threw themselves into the campaign for Bush's electoral defeat as if it were a transcendent calling to save the nation's honor and soul. As if by agreement, liberals, leftists, and radicals withheld building robust social movements on the causes that mattered to them, whether the environment or even opposition to the war. Instead, all energy fed a single, over-arching goal: beating Bush.

The perfect storm of anti-Bush resolve and resources seemed to gather. Unprecedented millions flowed into the coffers of an uncommonly united Democratic Party. A flood of acrimony, from the left especially, quickly drowned Ralph Nader's spoiler candidacy into statistical irrelevance. Progressives at last cracked the mainstream punditocracy and even got their own talk-radio station. A cottage industry of books of the "George Bush is a Dirty, Rotten, Semiliterate Idiot" variety sprang up to document his every lie and malapropism. Michael Moore stuffed his blockbuster 
documentary with unsparing derision and, in the image of a bereaved soldier's mother literally cursing the White House, heart-rending denunciation of the president. Hip-hop mogul Russell Simmons registered young minority voters in droves, while Bruce Springsteen led a star-studded tour of anti-Bush rockers through the swing states. Grass-roots groups like the satirical Billionaires for Bush used media-friendly wit and glamour to energize the antiBush faithful and educate the undecided about Republican class warfare. [13] The GOP unwisely chose New York City-claimed by Bush as the symbolic center of his "war on terror," but in truth the quintessence of multicultural, blue-state hostility-as the site of its nominating convention. (Bush would lose the five boroughs by a staggering two million votes.) And a small army of volunteers descended on Florida, Pennsylvania, and Ohio to make sure that "irregularities" not tilt this time a Democratic victory into a Republican upset. Finally, Senator John Kerry, whatever his patrician air and fickle voting record, brought to the fight great dignity, debating skill, and, as a decorated combat veteran and Harley Davidson rider, a conspicuously manly pedigree.

George Bush of course won, this time taking the popular vote by more than two million. His victory, in spite of the glaring wreckage of his presidency, is the defining fact and riddle of our political era. To be sure, the administration's misdeeds elicited obligatory hand-wringing, tepid apologies for the worst treatment of Iraqis, all manner of investigations, recommendations, and revised protocols, a few decent Supreme Court decisions limiting executive power, moments of Congressional indignation (notably, Senator Robert Byrd's jeremiads), and a groundswell of popular opposition. But when given the easy chance to at last reject Bush's tragic folly, some critical mass of "the people" - the vaunted sovereign and where the buck presumably stops-refused, as if they did not know, or did not care, or could not accept that they had been so grossly mislead, disrespected, and endangered.

The other half of the voting public was left crushed and shaken in its civic faith. Bitterness and sanctimony aside, one could not help but feel that Bush had held on to American hearts and minds by some means other than a conscientious, rational appeal. The case for his administration, prima facie, seemed neither credible nor persuasive. How could people not know or not care what it had done? Explanations for the outcome quickly piled up: that is what the four million evangelicals Republican strategist Karl Rove allegedly brought out this time to the polls; the surprise choice of so many voters to put "moral values" first in choosing their president; more cynically, the diversionary, eleventh-hour focus in key states on "culture war" issues like gay marriage; the rigid ideological demographics of a "divided America" tilting slightly in Bush's favor; or, correcting for all this, that a majority of voters simply felt safer with Bush in office (“It was 9-11, stupid!”). But each of these, if valuable as partial accounts, seemed incapable of solving a puzzle that seemed to stretch beyond the realm of certainty and the explanatory power of social science. Perhaps the intermittent campaign charge that Bush was "out of touch with reality" now held the vital clue. By this speculative drift, Bush had, above all, invited his supporters to participate in an alluring fantasy. In the world it imagined, all the comforting platitudes of his campaign held, no matter the mountain of highly public evidence to the contrary: that America is blessed with special virtue and divine favor; that its global enemies simply resent and envy its freedom; that the nation and the world are safer for Hussein's removal, and by that alone the war is just; that America only promotes, and never violates, human rights; that Iraq is fast on the road to democracy, and that the war is going well; that no important mistakes were made, and indeed that nothing could have or should have been done otherwise. Bush's victory, if rooted in this stubborn delusion, represents nothing less than the victory over-or ingenious (mis)construction of - reality. Long live the American myth of innocence!

Frustration on the left with the apparent blindness of the electorate or even "the people" is nothing new. It was certainly felt in the 1960s, when leftists had to contend with the enduring support of much of America for a war vastly more destructive than that in Iraq. And Nixon, in spite of the war's mounting toll and the sturm und drang of domestic protest, won in 1972 by a landslide. Nonetheless, there prevailed in most dissident quarters a basic faith in the judgment and capacity for initiative of the American people. One observer described that faith with respect to the war: 'We assume that most Americans don't 'really' will the Vietnam war but are morally asleep and brainwashed ... that there has been a usurpation by a hidden government which makes policy, and that an awakened populace can throw it off." [14] Hence, the effort over years to awaken the populace through education and protest, and, when power still proved deaf to antiwar appeals, to disrupt directly the war machine. But what to do, as now seems the case, when the theft occurs in plain view and is widely ignored in a seeming state of waking sleep? A more radical inquiry in the late 1960s into the will of the people asked how close America was to revolution, why "the masses" did not yet want some apocalyptic, social transformation, whether the "objective interests" of working-class whites lay on the side of empire or the world's oppressed, and so on. Somewhat fanciful even in its own time, such talk is light years from being relevant today. At issue is a far less ambitious awakening: merely having a fraction more than 
fifty percent of voters unseat a new, amply exposed usurper in favor of a candidate who in truth offered only modest alternatives on contentious issues like the war in Iraq or U.S. trade policy. If America can't do even that, the madness is not the president's, but ours.

To credit Bush's victory, in part, to a pervasive misrecognition of reality is to pose multiple analytic challenges and to invite diverse objections or even offense. The thesis plainly asserts that Bush's supporters possess a false picture of both his administration and the world. They are victims, therefore, of "ideology" as that mechanism which forces, by a standard definition, the "divergence between so-called social reality and [a] distorted representation, [a] false consciousness of it." [15]Whether an essentially naïve and manipulated consciousness holds this false picture remains an open question. The model of willful delusion sketched above suggests that something else is going on today-something akin to the subjects of the naked king in the famous fable insisting that he is clothed when they can clearly see that he is not. In this instance, the naiveté, paradoxically, is a choice. Whatever the case, there seems in the inscrutability and even shock of the election result new cause for ideology critique, less as the unmasking of false pictures than as an effort to understand the complex means by which ideology now works. The condescension implied by the endeavor - that Bush backers have reality wrong-is unavoidable, even if partisan bullying is not the point.

Skepticism may come from a rather different camp. The notion of misrecognition invokes a premise long contested by the postmodern habit of mind: that there exists a stable reality "out there" than can be represented in ways more or less truthful. Reality and truth, decades of postmodern theory counseled, are contingent social constructions, all but obviating the category of raw cognitive error and the forms of ideology critique that draw on it. Moreover, postmodern thinking has doubted the existence of an epistemological ground from which judgments of truth and error could even be made. The main goals, of course, were to destabilize dominant constructions of reality by knocking out their metaphysical supports; to valorize the claims of dissident and marginalized groups; and to argue the benefits of liberation from "the truth" — as a prime weapon of the powerful—altogether. That said, a portion of postmodern animus was always directed at the Marxist hermeneutic of truth and error, the stipulation - with its hoary vanguardism — of "false consciousness," and the historic implication of these in systems of domination. With whatever irony, political conservatism and theoretical experimentalism may share hostility to self-professed bearers of truth.

Neither camp, however, need feel so scandalized. A dialectics of truth and error has a venerable place in the metaphysical heritage of "the West" or the "Judeo-Christian" world. Its root is the Platonic insistence that things are not as they conventionally appear-indeed, that reality comes to us in distorted form. The deepest knowledge entails piercing the fleeting realm of appearances to apprehend things as they essentially are. Centuries of Christian theology sustained this duality of appearance and essence by positing that the true nature of divinity is largely concealed, whether by the intricacies of the divine text, the distraction of heresies, or the mystifying otherness of God himself. Union with the divine, never made easy, requires special qualities of insight, piety, or faith. In more modern and experiential terms, the evangelical notion of being "awakened" or "born again" posits that one may long dwell in sinful ignorance of God's love, only to be brought into the saving light of faith by which one then "sees" the reality of God's immanence. A social application of this principle, moreover, is endemic to modern, American religious conservatism. Abortion foes, for example, commonly claim that a "baby Holocaust" is daily taking place; the urgent task is to get Americans to see the truth of this moral horror behind the ideological haze of a supposed right to privacy and, once awakened, purge the sinful conduct from the nation. If one can accept these kinds of individual and collective passage from darkness to light, why not also the possibility that a false prophet on the political right can condemn his voting flock to a dangerous blindness?

Conversely, a postmodernist on the left may find it hard to do without at least soft versions of "the truth" and "reality." How else does one make either the straightforward charge that, for instance, the "Swift Boat Veterans for Truth" falsified Kerry's record in Vietnam, or more ambitiously, that Bush has promulgated fraudulent narratives about the motives for and course of the Iraq war? Somewhat tendentiously, as Ed Rothstein argued in 2001 in the New York Times just after 9-11 that postmodern relativism, taken to its extreme, leaves one powerless to condemn evil such as the Al Qaeda attacks. The logic of Rothstein's admonition, turned against its intent, also limits the power to denounce the wrongfulness, if not outright evil, of the Bush administration. A postmodernist may want to squander neither capacity, even if it means tempering skepticism and analytic acrobatics.

This may be the time, moreover, for ardent postmodernists to keep open minds regarding concepts like "truth," 
"reality," and "narrative" that have long been the objects of their critical gaze. 9-11 has scrambled the meaning and agency of these terms. Merely reflecting on whether the attacks and their complex aftermath have repudiated or confirmed the postmodern condition induces a kind of interpretive vertigo. Did 9-11 not represent, according to the eminent theorist-provocateur Slavoj Zizek, the crashing in of the Real, with its very literal load of death, on a culture long protected in the bubble of its projections and virtual realities? That tragic day thus forced America's rediscovery of "the world" - both as a vast space of suffering beyond its privileged borders, and as the realm of reference as such beneath the scrim of the hyper-real. [16] And yet, in 9-11's wake, hasn't the world been banished from America once again, its sufferings-including American war deaths_kept mostly out of sight and out of mind? And hasn't "reality" seemed as fungible as ever-the plaything not only of dreary television shows, but of partisans and propagandists, the coveted prize in newly raging discourse wars tethered to an election of global importance? The indeterminacy of our current moment demands permitting the existence of multiple and even contradictory logics, such that "reality" and "truth" both do and do not have substance, that our age may be both supremely ideological and post-ideological all at once.

Ideology as "false consciousness," a concept known to any college sophomore, comes of course from Marx. It describes the state of ignorance of the wage-working masses regarding the nature of their oppression and the path to their liberation. Marx sought, however, to explain and not merely decry this ignorance and its benefit to capitalists. In the mature theory of Capital, the root of false consciousness lies in the reification or fetishism inherent in commodity exchange, whereby social relations among people are mistaken for economic relations between things. Far from a simple failure of vision, this mystification is the condition of possibility for the operation of capitalism itself. To cast it off is to enter the road of freedom, but also to imperil the context for one's social existence, however much already compromised or degraded. This awakening is therefore neither easily done nor even embraced. Workers may have had nothing to lose but their chains, but Marx could understand their odd comfort in remaining bound.

Italy's Antonio Gramsci greatly enriched Marx's critique of ideology in ways especially fruitful for future theory and resonant in our time. According to Gramsci, ideology is not a more or less static effect of a mystifying structure. Rather, it is dynamic and often unstable, sustained by processes of hegemony in which the ruling class makes its values and ambitions those of the people it exploits. The misrecognition on the part of the exploited thus occurs as a debilitating identification with classes, points of view, and sensibilities antithetical to their true identity and interests. And because ideology functions mostly through discourse, not repression, this illusory sense of affinity is overwhelmingly voluntary; hence, the vital questions for political actors of who controls the means of ideological production, how those means are used, and which discourses-whether those of the media, the state, or the education system-most powerfully condition popular belief and practice. Finally, hegemony can be at least partially undone by commandeering discursive power. Class conflict, within this model, largely takes the form of discourse wars over the interpretation or representation of social reality.

Herbert Marcuse, the arch-theorist for 1960s radicals worldwide, substantially separated ideology from class oppression as such. Advanced capitalism, he asserted in the early 1960s, had neither a single locus of power nor class of victims; its destructive capacities, such as ecological devastation and existential impoverishment, imperiled everybody. But Marcuse retained the charge that "the system"- still predicated on logics of domination benefiting a corporate-political elite-sustains itself by inducing pervasive loyalty to it. The means for this were forms of "one-dimensional" thought and culture ranging from instrumental rationality, to a vapid media, to the ethos of conspicuous consumption. Their effect was to dramatically inhibit critical or "negative" thinking by reinforcing the illusion that the existing world is the best, and indeed only possible, world. The limited dissent that did exist was quickly neutralized by being absorbed into the political and cultural mainstream or, as in the case of the rage of poor urban blacks, pushed to the distant margins of public concern. In the face of this, Marcuse encouraged anyone so inclined to participate in "the Great Refusal" of the system in its totality.[17]How heartened he was, then, to see so many takers for his audacious plea, who would help make "the Sixties" happen.

However intermittently influential for the American left, ideology critique of the sorts outlined above fell into almost total disfavor from the mid-1970s on. The decline partly reflected a broad shift among progressives from a politics of class to one of identity. Left-wing intellectuals developed a new appreciation of the complexities of power and a new humility regarding the ability to demarcate "reality" with any great certainty or script how people "should" think and act. And with the right seizing the mantle of populism from at least the days of Ronald Reagan, anything from the mouth of candidates suggesting cynicism as to the thoughtfulness and good judgment of "the people" 
smacked of an intolerable elitism that only strengthened the conservative hand.

What a surprise, then, to see in this last election cycle the evocation of the spirit (though not the letter) of decades of accumulated, broadly Marxist wisdom. Loosen from Gramsci's model its focus on class and its normative commitments, and it anticipates today's recognition of the central importance of language in political struggle. The province of neither the left or right, this awareness can everywhere be seen: in the obsessive charge of each that its rival controls the media and drenches it with bias; in the consensus crediting of the right's success to its ability to define the terms of debate by disciplining its ranks in the use of specific words and "talking points"; in the desperate attempt of the Democrats to reframe debates, whether by stealing from the Republican playbook or taking the more targeted instruction of the progressive socio-linguist George Lakoff; and in pundits' assessments of how the Republican Party presented the more compelling "narrative" of the country's destiny and how its candidate would take it there. Among the mainstream media, it is more and more assumed that American politics is a contest not over who has the truer or better picture of the world according to some normative criterion (such as what might be most beneficial for the country), but rather over whose picture is more effective in garnering publicity, financial contributions, and votes. [18]

More surprising still has been the return with such great vengeance of an unapologetically class-based and militantly partisan version of ideology critique-one that, at bottom, accuses the Republican Party of mass deception and the American people of mass stupidity. I refer here to Thomas Frank's (2004) brilliant preelection study What's the Matter with Kansas?, a book that almost functions as a metonym for a growing species of defiant, progressive critique of political conservatism. Too easily appreciated (or dismissed) simply as an entertaining polemic, Frank's landmark study of American political consciousness warrants close scrutiny.

In the question posed by his title, Frank really asks what's the matter with America. His answer can be easily summarized: working- and middle-class Americans should be livid with the corporate-political class, represented most purely by the Republican Party. It uses trade agreements, tax cuts for the wealthy, corporate welfare, and all manner of deregulation to outsource their jobs, destroy their family farms, bankrupt their cities and towns, crush their unions, make health care unaffordable, and mortgage their children's future. (The devastation is especially acute in Frank's native Kansas, which he describes with intimate sorrow.) But instead of shunning their structural adversary, legions of suffering Americans dutifully vote Republican and effectively support the policies that bring them ruin. He laments, "people getting their fundamental interests wrong is what American political life is all about. This species of derangement is the bedrock of our civic order" (2004:7). Without once uttering the word "Marx," he argues that America is awash in plainly false consciousness.

Frank's ingenuity comes in his revelation of how the derangement is essentially a ruse. Americans, and red state dwellers especially, feel plenty of rage against elites. But rather than directing it at their economic overlords, they aim for an alleged cultural elite that is stereotypically liberal, secular, educated, urban, politically correct, well-connected, and "effete." This "elite," in the phantasmatic construction of cultural conservatives, is destroying their values with its decadence, their pride with its condescension, and the certainties of their faith with its relativizing intellectualism. At once instigators and opportunists of misplaced anger, Republican leaders essentially buy the loyalty of voters-and therefore support for their corporate agenda — with largely rhetorical patronage in perpetually raging culture wars. In these, they play the down-home heroes of their humble countrymen, while castigating the opposition as inauthentic, out-of-touch, and un-American.

For the conservative rank-and-file, the seeming bargain is less a fair trade than a raw deal, as the point of its true beneficiaries is not actually to win the culture wars, and the tangible gains are indeed few. Rather, the point is to keep large swaths of the public endlessly fulminating at an illusory foe and squarely within the Republican camp. (Hence, Frank's observation that indignation, as bellows from any conservative talk radio station, is the quintessential pose of the cultural warrior.) Furthermore, Frank describes what he bluntly calls "the trick": "Vote to stop abortion; receive a rollback in capital gains taxes. . Vote to get government off our backs; receive conglomeration and monopoly everywhere from media to meatpacking," and so on (p.7). Instead of the Great Refusal, in sum, Americans have opted for "the Great Backlash," defined by a tragic contradiction: "it is a working-class movement that has done incalculable, historic harm to working-class people."(2004:6)

Frank's study is not without its tensions and flaws. By his read, culture wars are for their master-architects essentially diversionary, such that losses are eminently acceptable. One may observe that popular entertainment is choked with gratuitous sex and violence, despite conservatives' vocal offense at this; that Will and Grace is a beloved sitcom, despite right wing disgust at the purported imposition of "the gay agenda" on good Americans. By a 
thousand measures, conservatives are losing on issues where their passion seems strongest, and Frank helps explain why. Frank, however, overlooks that some cultural warriors are dead set on actually winning and minimizing their very real victories-from functionally eliminating abortion services in much of rural America, to constitutionally blocking same-sex marriage at the state level, to stacking the federal judiciary with conservatives. In structural terms, Frank asserts the primacy of the economic so forcefully that culture becomes little more than a repository for misplaced economic grievances. Like so much Marxism, he thus denies culture its limited autonomy and the legitimate stake of activists, whether of the right or the left, in morality as such.

In addition, Frank leaves rather murky just how this grand ruse is orchestrated. Who was so ingenious as to first figure out and then coordinate it, year after year, election after election? At times, Frank implies the existence of a plutocratic Republican minority that shrewdly calls the shots. At other times, the ruse seems less the doing of a literal conspiracy of rich guys and their strategists than a mechanism built into the operation of corporate capitalism itself, whose players become incidental functionaries of a structural logic. In this model, something as abstract as "capital" becomes the preeminent agent of American politics and culture. Specifying the precise means by which ideology functions is admittedly difficult, but doing so may be crucial for its sabotage. Moreover, the New Democrat Bill Clinton, with NAFTA and welfare "reform," himself advanced a free market agenda largely without summoning for cover the tropes of the culture wars (his upbraid of Sister Soulja and obvious Bubba-appeal are modest exceptions). This begs the question of how much the rich really need the culture wars to get what they most want.

These limitations, however, hardly compromise the polemical and even analytical power of Frank's study. Frank articulates with an appropriate sense of horror the virtual psychosis afflicting America: "The country seems like a panorama of madness and delusion worthy of Hieronymus Bosch: of sturdy blue-collar patriots reciting the pledge while they strangle their own life chances; of proud farmers proudly voting themselves off the land; of devoted family men carefully seeing to it that their children will never be able to afford college or proper health care" ( $p$. 10). In such rhetoric, penned before the election, Frank enunciates the same basic stupefaction in which I wrapped my account of Bush's victory, the same anguished bewilderment at Americans' apparent choice to be, in his phrase, "happy captives." [19] He has, in short, the problem right.

Frank's anguish derives almost exclusively from an analysis of domestic politics, and mine from Bush's foreign policy. Yet, Frank provides material for linking in new ways domestic and foreign concerns, culture wars with the "war on terror." With these linkages, a kind of master diagnosis emerges of a multi-symptom disease in the American body politic, in the American mind.

In describing the deep psychological appeal of "the backlash," especially among white men, Frank asserts that it "is a theory of how the world works, but it also provides a ready-made way in which the glamour of authenticity, combined with the narcissism of victimhood, is available to almost anyone. . You're the salt of the earth, the beating heart of America, the backlash tells [you] . . But now [you], too, can enjoy the instant righteousness that is flaunted by every other aggrieved group" (p.157). In this cast, soldiering in the culture wars provides a subjective, if largely illusory, sense of empowerment as a response to a subjective sense of injury or wounded pride, ultimately rooted in economic malaise.

On September 11, 2001, the United States was of course attacked, imposing on its people a victim status that was very real and which made the country, for a time, an uncharacteristic object of global sympathy. Clearly, the strikes left a massive psychic and even spiritual wound in Americans. A bumper sticker appearing after 9-11 asserted the sacred cast of American nationalism, while hinting at the depth of the wound and, perhaps, the wrath to come: "America is My Holy Land."

Both fascinating and scary has been the United States' reaction-one so severe and so zealous that is seems to transcend good military and political sense and draw on reserves of traumatized rage emanating directly from the wound. That is, so much of the "war on terror" exceeds, prima facie, the conscientious pursuit of greater security: from the wanton incarceration of so many harmless foreign "enemies"; to the flouting of international human rights standards America once championed; to the abusive detention and mass deportation of immigrants (albeit often illegal) posing no security threat; to absurd degrees of domestic surveillance that compromise the very freedoms in whose name we are fighting; to the costly invasion of a country posing no military threat; to a professed crusade to bring democracy to the world at the barrel of a gun. If of doubtful security value, all this may nonetheless accomplish something very important with respect to 9-11: to make Americans feel again proud, tough, invulnerable, virtuous, and superior, with all means for doing so metaphysically justified by the apocalyptic injury the country endured and its newly proclaimed (if widely contested) identity as global arch-victim. In this role, the "war on terror" reproduces 
the basic formula of the culture war: misdirected anger as dubious, if not downright self-injurious, compensation for a perceived loss of pride, prestige, power, and security.

One can see with reference to the international arena a striking reflection of the archetypes and tropes of the domestic culture wars. To the red state patriot, the native liberal is now the sanctimonious, over-cultured, and patently wimpy Frenchman. The indigenous "blame America first" crowd becomes the international community tout court, which can neither recognize, let alone appreciate, America's benevolence. The nativist suspicion of multiculturalism endemic to the culture wars becomes hostility to a whole globe of America-bashing others. The peculiar blend of resentment at and envy of domestic groups claiming victim status-minorities, women, gays-is now felt toward entire geographies (the "Third World" or "global south") and "civilizations" (Islam, by a crude construction). If they can have their holy wars, their jihads, why can't we? Is our God, are our values, any less worthy of defense? Finally, Bush's pursuit of global democracy amplifies the virtue of his earnest backers: they are the beating heart of America, and America is the beating heart of the world. By these mediations, the backlash goes global.

In arguing the globalization of the backlash one asserts a kind of primacy of culture that challenges Frank's hierarchy in which economy is the dominant, if often covert, cause of politics. Consider the Iraq war, perhaps the purest case of displaced rage within the "war on terror." Tenuously or not, leftists have denounced it as a war for oil profits masquerading as one of preemption, and, more recently, liberation. But one can see it in different terms altogether: as a war "really" fought to restore wounded pride or, perhaps, exact a vengeance not satisfied by the easy conquest of feeble Afghanistan. National security is sacrificed not to economic interest but to psychological and cultural need.

There is a sense, however, in which Frank's analytic emphases may hold, giving him the last sad laugh. A plausible case can be made that before Bush even entered the White House, a clique of neoconservatives sought a U.S. invasion of Iraq in order to establish a beachhead for, above all, the political and economic pacification of the oil-rich Middle East. 9-11 provided the occasion to execute this audacious, essentially imperialist plan. (Neil Smith's Endgame of Globalization [2005] offers a compelling version of this controversial charge. Smith does not weaken his argument by dismissing Bush's rhetoric of spreading democracy as a smoke screen. Rather, he shows how such rhetoric has always accompanied American imperial ambition, tingeing greed with idealism, and vice versa. Whether or not the dismally expensive conflict has as yet been remotely worth it from an imperialist standpoint is another matter.) To a security-crazed citizenry, manufactured fear of Iraqi WMD provided the war's rationale; the aching desire to strike back, to lash out_even if against the wrong "enemy" — provided its necessary public passion. America stands fooled again by the same Frankian logic, as a corporate-political elite manipulates mass emotion for economic gain.

The raw deal can be described, iconically, as the "Halliburton effect": the American taxpayer now holds an openended bill for an abjectly unnecessary and possibly unwinnable war that is nonetheless sure to earn the vice-president's corporate friends untold billions in reconstruction contracts. Yet, the rip-off is worse still when considering its ultimate cost and who pays it. The demographics of the volunteer military notoriously fall towards the bottom of the economic ladder. Geographically, servicemen and women are drawn disproportionately from America's vast pockets of economic decline or blight, notably those in the Midwest, Appalachia, the Rust Belt, and the rural and small town South. In other words, our wars are fought by refugees from the dead-end jobs, dreary monoculture, and dismal life prospects of red state America. (Archetypically, the young volunteer to earn money, get an education, and see the world; saying so is not to doubt the strength or sincerity of their patriotism.) It is, then, precisely the shabby economy of the vaunted heartland and its coastal tributaries_- no matter how many Wal-Mart jobs they may have, no matter the sublime authenticity of their culture - that generates a standing army large enough to carry out the imperial strikes of the rich and powerful. In this, the "trick" on the culture war die-hard takes its most obscene and tragic form: Vote for a straight-shooting, tough-talking Texan who will keep America safe and strong; receive a deceitful war that will explode the deficit, stoke hatred of America, and which may kill your son or daughter.

The final virtue of Frank's study is the powerful simplicity with which he explains, and not just poses, what's wrong with America. To the "how could they?" quality of Americans' misdirection, he answers in essence, "It's ideology, stupid!" — and of a rather primitive sort. That is, people still can and do possess fundamentally erroneous understandings of reality that are manipulated by a more or less coherent ruling class.

What saves the book from either unbearable arrogance or pessimism is Frank's implicit faith that it is still possible to use facts and reason to appeal to people's truly enlightened self-interest. What saves it from self-trivializing 
idealism is that the awakening Frank seeks is nothing so grandiose as a "revolutionary class consciousness" desiring "socialism"; rather, he seems to favor the common-sense pursuit of economic policies, like uniformly living wages, universal health care, and greater market regulation, which threaten only to give capitalism a more human, egalitarian face. The implications for progressives, whether Democrats or not, are clear: in terms of message, to return to economic populism, like the Kansas Populists of the nineteenth century and generations of rather successful Democrats in the twentieth century. [20] In terms of strategy, to practice a relentless politics of truth that educates people about the source of their anger and directs it in the right place-at the right. This means fighting discourse wars with new focus and rigor, mobilizing every available species of media, cultivating a winning arsenal of key words, images, and narratives, and being vigilant in not offering up easy fodder-like photo-ops of the Democratic candidate windsurfing near his fourth home-for the reinforcement of "liberal elite" stereotypes. [21]

Crucial to all this is unsettling the affinity between the Republican powerful and their dutiful followers, but with a twist on what Gramsci's notion of hegemony might recommend. The counter trick is not so much to break people's spurious identification upward with the rich; rather, it is to show the opportunism and falsity with which plutocrats identify downward with the masses by appearing to share their moral anger, lead their crusades, and even echo their average-guyness. (Could Bush's victory in the "Who would you rather have a beer with?" sweepstakes alone explain his reelection?). With whatever impact on the electorate, the Billionaires for Bush performed this complex semiotic operation with great skill as they visited Bush rallies and shopping malls in swing states. Wearing top hats and tiaras, speaking in condescending tones about "the little people," and ritually thanking Americans for paying their taxes and fighting their wars, their message was this: the Republicans are your false friends; they do not ultimately think like you, look like you, or care about you. But they ring up, year after year, your vote. [22] In using hyperbole to cast away the spell of misidentification, the cunning logic of the culture wars stood exposed.

A more partisan optimism issues, finally, from the Frankian meditation. However deep America's current madness, the cure outlined above is not so exotic after all. Doses of it were already applied during the campaign. In the most daring protest at the Republican National Convention, activists dropped a banner over four stories of New York's Plaza Hotel. On it was an arrow bearing the word "truth"; below, and pointing in the opposite direction, was another with the word "Bush." The whole sign points, from a strategic perspective, in the right direction. Redoubled commitment to a politics of truth, moreover, is just what so many in the anti-Bush ranks prescribed for themselves in the literal and figurative mornings after the election. As the postmortems evolved, nobody has been saying that the cure will come quickly or easily. It will take, by consensus, time, money, courage, and will. And with any luck, some cosmic twin of Bill Clinton's, more genuinely liberal but with the same poor white roots, "aw shucks" charm, and ability to make Americans feel that he feels their pain, will emerge in 2008 to spike the saving potion.

With the resurgent diagnosis of false consciousness, the Gordian knot of American politics, tied like a tumor in the American mind (with complications for the heart), seems already to loosen. The prognoses in progressive circles might be genuinely good were there greater actual faith in the cure. At one level, progressives harbor troubling doubts that they can win at the politics of truth. The lament is familiar: that it's clear which side media conglomeration favors; that the right's bromides and simple pieties reduce well to sound bites, while the nuanced views of liberals and leftists do not; that conservatives' pockets are deeper, their institutional base and reserve of "social capital" in the evangelical churches far richer than anything on the left; that it's hard to keep Americans from rallying around the flag and their president (or his party) in times of war; and that the Bush administration has shrewdly constructed this war and its accompanying state of near-emergency as permanent. Yet there is the even deeper and more dispiriting worry that under current conditions a politics of truth can't work, and here the problem is not one of resources or stamina, but of structure. Hinting at the problem, Senator Hilary Clinton recently fulminated at the right, "I know it's frustrating. . Why can't the Democrats do more to stop them?. . It's very hard to stop people who have no shame about what they're doing. . It is very hard to stop people who have never been acquainted with the truth.” [23]

Intense partisanship and ideological polarization always entail deep chasms between the worldviews of political rivals - intense disagreements about "reality" and "truth." There seems in recent years, however, a qualitative mutation in the field of discourse itself, such that no viable context exists any longer for the mediation of competing truth claims, little or no terrain even for an honest battle over hearts and minds. Sensing this, an exacerbated editorialist asked: "Is it possible in America today to convince anyone of anything he doesn't already believe? If so, are there enough places where this mingling of the minds exists to sustain democracy?” (Miller 2005:A15) The problem, he intuited, was not simply the stubbornness of strong belief. 
Americans today seem to live in alternate semiotic universes, whereby ideological divisions reflect different profiles of media consumption. Thus, the "NPR liberal" and "Fox News conservative" become antipodes in a nearontological stand-off of quintessentially discursive identities, with neither allowing its corruption by the stories, spin, and ethos of the other's media culture. In plainer language, each "side" seems to have its own passionately held and rigidly inoculated "truth."

At a more disconcerting extreme, and within the universe of the right, that inoculation may ward off the challenge of anything approaching "reality" altogether: certain vital facts, in the dark corners of ideologically-induced information fog, either do not appear or do not minimally register. This can lead to essentially hallucinatory-yet politically powerful-misperceptions, in which the derangement of American consciousness again rages. Perhaps the most disturbing political data of recent times have been polls showing that garish percentages of Americans believe, without a shred of evidence, that Hussein was involved in the 9-11 attacks and that a number of the hijackers were Iraqi. In September of 2003, a Washington Post poll had 69\% holding the former belief. [24] Bush, sensitive to charges that his administration had deliberately fostered this untruth, quickly clarified, "We have no evidence that Saddam Hussein was involved with the September 11 attacks." But he then added, dubiously, "There's no question that Saddam Hussein had Al Qaeda ties." [25] The myth of Iraqi involvement in 9-11 persisted through the election and endures to this day. (A Harris poll of February 2005 showed that " 47 percent believe that Saddam Hussein helped plan [the attack] and support the hijackers," while 44 percent believe that several of the hijackers were Iraqis.) [26] The myth's strength, in the face of countless refutations, has led critics to suspect that the Bush administration knows that insinuation is enough to throw many Americans off the trail of reality-that all on their own, "the people" will morph innuendo and small misstatements of fact into Great Lies, bleating from the administration any obvious culpability.

From this instance of derangement, it is tempting to conclude that what America most needs-prior to any partisan reawakening - is a massive re-education in basic political literacy and civic competence. Only then would a national conversation about controversial issues be minimally rational and therefore democratic in the elevated description of democracy's original Anglo-American champions. (In the meantime, progressives may have to write off a certain numbskull constituency among the public, and hope that it doesn't vote in large numbers.) However salutary, making such civic competence the priority would be, I think, to misunderstand the depth of the pathology when popular beliefs, and the discourse wars within which they are shaped, are so little tethered to or regulated by credible reference to "reality." That is, broader public agreement on a larger body of facts goes only so far in addressing how the realms not only of "fact," but of "value" as well, are under assault.

Engaging briefly the issue of the persistence or eclipse of the postmodern condition helps to define that assault. In his seminal work of 1979, the French philosopher Jean-Francois Lyotard defined postmodernity in terms of the decline of the West's master narratives like "emancipation" or "equality" and the exhaustion of utopian energies for their fulfillment. (Lyotard 1979) Yet we patently seem in a new era of the grand narrative, insofar as both the "war on terror" and the extremist war on America have a manifestly epic cast. With messianic ambition and militarized zeal, Bush trumpets his fight against terrorism as one for the Enlightenment's core ideals: democracy, liberty, secular government, religious pluralism, political equality among groups, and human rights. From the other side, radical Islamists seek to use spectacular violence to cleanse the world of the moral corruptions-from the desecration of tradition to libertine indulgence — of a great infidel empire. [27] In an apparent rebuke of Lyotard, the perceived stakes of conflict seem to be getting bigger and more idealistic, not smaller and less so.

At the same time, Lyotard prophesied that political conflict would increasingly take the shape of discourse wars among newly proliferate, and often highly local, narratives. Lyotard seems to have the quality of the struggle right, but its number and scale off. Indeed, America's current polarization and much of the global debate over U.S. power can be described as a battle of two, epically contrasting narratives-themselves large in scope and import-over whether Bush is truly advancing or irreparably harming the Enlightenment narrative and its constitutive ideals. This conflict has raged in the recent war of words between Amnesty International, the London-based custodian of international "human rights," and the Bush administration. In a well-publicized report, Amnesty charged that features of the "war on terror" have made the United States one of the world's conspicuous human rights abusers and likened its network of detention facilities to a global "gulag" — a word evoking the negation of liberty by America's historic, totalitarian foe. Bush himself dismissed the charges as "absurd," insisted that America is the world's leading human rights defender, and, in a perfect gesture of the global backlash, denounced the report as the product of people who "hate America." [28]However one scores the debate, it pulses with concern over values and the nation's moral destiny. 
Lyotard made a final prediction, with chilling implications to the extent that it may be coming true: that the power, salience, and truth of narratives would depend less and less on their correspondence to "reality" or normative integrity, and more and more, within an ascendant commercial-operational logic, on their efficacy in achieving instrumental ends. Bluntly stated, it matters not which narrative is truer, only which is more effective, evacuating moral concern from what he calls the "legitimation" of knowledge.

Lyotard's prediction begs the question of what criteria determine efficacy. Lyotard's own eye was mostly on technology; the kind of question implicit in his inquiry was, for example, whether moral misgivings would have any power to arrest the development of cloning technology, with its tremendous intellectual momentum, social application, and commercial potential. Shift to contemporary politics, and worrisome possibilities appear. One pertains to politics in the relatively superficial, but nonetheless potent, sense of the horse race, of the American obsession with winning and losing. By its metric, partisan advantage is what most counts in crafting and assessing political discourse. Consider Bush's quip that the Amnesty authors "hate America." The slight-red meat for the Bush faithful-permits Bush to avoid, in Amnesty's apt words, "dealing with the details or the facts," while turning the report's evaluation into a referendum on how one feels about the United States. Making defiance of the international community the measure of true patriotism is of course a standard weapon in the right's rhetorical arsenal-one used to great effect in Bush's repeated, fallacious charge prior to the election that Kerry would require that the United States "ask foreign capitals" for permission before defending itself. What this example suggests, amplified by the myth of an Iraq-9-11 connection, is that if some mass of the public believes in a given narrative or image of reality, and this belief helps one win, then the story or picture is as good as true, and the facts don't matter. Hence, Karl Rove, the master of rhetorical sleight of hand, is widely praised as a brilliant strategist, when he could just as easily be condemned as a craven propagandist.

This circumstance is laden with irony. For their assaults on "truth," postmodernists have been castigated as the great at relativisms; yet postmodern theory, in the manner above, helps disclose in contemporary political discourse a kind of relative logic-one so powerful that the return to grand, morally rich narratives and disagreements over them has not arrested the instrumentalization of political life and the functional decline of moral concern. In a second irony, conservatives are widely credited with asserting in the last election the importance in public life of moral values. Part of their dislike of Kerry was for his alleged "inauthenticity"-the perception (hard at times for Democrats to refute) that he would do anything, say anything, and appear to be anything in order to be liked and to win. Bush purportedly "stood for something." Yet it has been much more the right, with its distortions of reality and propagation of myth in the name of political gain, that has permeated political debate with the inauthenticity of image-craft and a win-at-all-costs attitude.

There is, however, winning in a grander sense, generating another cold standard for assessing narratives' efficacy: the degree to which they enable the United States to fulfill its imperialist prerogatives. Within Neil Smith's argument, representing here a whole genre of new critiques of empire, the endgame of the Iraq invasion is the extension of U.S. economic power. Thus, it can succeed even if its current, touted goal of bringing freedom and democracy to Iraq bogs down or fails altogether. Lest one think this unduly cynical, Smith invites the reader to contrast two things: on the one hand, the alacrity with which the United States, under Paul Bremer's early leadership, lowered Iraq's tax rate, liberalized its foreign investment laws, reduced its import duties, developed corporate stakes in Iraq's oil industry, and secured mammoth reconstruction contracts for U.S. firms; on the other, the great difficulty and even sloth with which the United States has restored basic services to Iraqis, helped to rebuild the everyday economy, provided security, and cultivated democratic institutions. (Smith 2005:176-191) By Smith's tally, what the occupation has mostly achieved so far is a kind of structural adjustment by invasion, earning Bremer also a Medal of Freedom. (In this light, Wolfowitz's new tenure at the World Bank makes perfect sense.) Returning to the fate of "reality," the narrative of Iraq's democratization is functionally true not to the extent that Iraq actually becomes democratic, but to the extent to which it provides a context and rationale for the achievement of the United States' economic goals. Imperial might, when applied successfully, makes its own alibi right.

Should one think this formula too simple or cynical, consider the fall 2004 comment by an unnamed senior White House adviser to a New York Times Magazine reporter:

The aide said that guys like me (i.e. reporters and commentators) were "in what we call the reality-based community," which he defined as people who "believe that solutions emerge from your judicious study of discernible reality." I nodded and murmured something about enlightenment principles and empiricism. He cut me off. "That's not the way the world really works anymore," he continued. "We're an empire now, and when we act, we create our own reality... We're history's actors. 
.. and you, all of you, will be left to just study what we do" (Danner 2005).

At first glance, this seems a triumphal, almost caustic, expression of the Bush administration's view of itself, in Hegelian fashion, as "world-historical." The administration makes history, dammit, while timid naysayers and equivocating scholars stand on the sidelines of destiny merely to watch. And America's destiny is to be an empire, not just of power but of virtue, advancing the grand story of freedom's march.

This may be, however, crediting the quote with an idealism it does not have, for nowhere does it mention freedom or any other virtue. One commentator, despairing at the encroaching irrelevance of facts in American politics, sees in it the frightening boast that "power . . can shape truth [and] determine reality, or at least the reality of what most people believe-a critical point, for the administration has been singularly effective in its recognition that what is most politically important is not what the New York Times believes, but what most Americans are willing to believe" (Danner 2005). This despair, while echoing my own, evokes also the concern of the Times' Frank Rich for the fate of his profession. Mortified by the White House allowing into its exclusive press conferences the "fake" journalist "Jeff Gannon" to pose "fake" questions, Rich (2004) leveled the charge: "Conservatives, who supposedly deplore post-modernism, are now welcoming in a brave new world in which it's a given that there can be no empirical reality in news, only the reality you want to hear (or that they want you to hear)" [29] (p.20). This small transgression of the boundary between the real and the fake points to a much larger one: the waging of a very real war based on a faked cause.

To the celebrated journalist Seymour Hersh, the Bush administration's simultaneous disregard for and manipulation of reality spurred an even greater revulsion. After recounting Bush's preposterously rosy assessments of the war in Iraq and America's moral record in the "war on terror," Hersh (2004) offered, "There are many who believe that George Bush is a liar [who] knowingly and deliberately twists facts for political gain. But lying would indicate an understanding of what is desired, what is possible, and how best to get there. A more plausible explanation is that words have no meaning for the President beyond the immediate moment, and so he believes that his mere utterance of the phrases makes them real" (p. 367).

In the hands of the new, covert postmodernists, empire seems to have taken the "linguistic turn," giving the quote of the White House aid a final, chilling salience. Attaching to empire no higher purpose or even instrumental end, its author defines power, in its purest form, as the ability to assert one's will as such. One does so not through the control of territory and resources, not in the allegiance of the minds and hearts of variously pacified or grateful subjects, but-by the ultimate discursive conquest-in lordship over "reality" itself. Yet this brave new world, in the ironic march of history backward, turns out to be rather like the old one. When sketching the postmodern condition, Lyotard (1979) largely celebrated the dissolution of master narratives and their utopian impetus; these, he felt, may have spurred progress, but they also lay at the heart of modern totalitarianism, which he defined as a "dangerous fantasy to seize reality" (p. 112).

In this dystopian image, an analytic null point has ostensibly been reached, such that it is time to take final stock of the proposed remedies for America's derangement and choose among them. Frank counsels that we turn false consciousness true by unmasking both the reality behind the veil of ideology and the devious means by which it is covered over. A second therapy deepens civic competence to restore an appreciation of facts and the means for making politics accountable to them. The most systemic approach demands greater public stewardship over the very idea of reality. But alas, the pathology is complex and substantially new; each remedy is necessarily experimental and likely, in itself, inadequate. Therefore, a holistic treatment combining the strength of each seems best. By a military metaphor, we need a coalition army in the discourse wars-networks of citizens' militias of every possible political persuasion, group identity, intellectual bent, and skill set to fight at once for facts, truth, reality, reason, and justice.

This call to arms avoids, however, the nagging problem implied by the early image of subjects making the naked emperor clothed. That is, it places ultimate faith in the power of revelation-the premise that if you expose the trick and publicize its cost, the captive audience will abandon the illusion and even turn on the illusionist. One may protest: aren't there already enough damning facts out there, and in plain enough view? Shouldn't some tipping point of disgust with Bush have been reached long ago, no matter the vagaries of ideology? This protest suggests that there already is enough of the medicine in the system, such that the diagnosis may still be off. Exploring this possibility requires that we cast our net one last time into the waters of social theory.

In the late 1980s, Slavoj Zizek invoked the idea of “cynical reason,” first developed by Germany's Peter Sloterdijk, 
in assessing the status of ideology in the modern West. Sloterdijk saw the decline of the "naive consciousness" victimized by traditional ideology and the rise, in Zizek's phrasing, of a new "cynical subject . . quite aware of the distance between the ideological mask and the social reality, but who nonetheless insists on wearing the mask." Possessed of an "enlightened false consciousness," this subjectivity is defined by contradiction: "One knows the falsehood very well, one is well aware of a particular interest behind the ideological universality, but one still does not renounce it" (Zizek 1989:29). Against the Marxian formula of ideology as mystification_-"they do not know what they are doing, yet they are doing it" — cynical reason holds: "they know very well what they are doing, but still, they do it." (Zizek 1989:29)

The idea of cynical reason provides new perspective on the mysteries of American politics. Above all, it dispenses with the assumption that people are fooled. Following from this, many Americans may well know that they were tricked into war, yet still support it as if it were no trick at all; know that the culture wars are a ruse, but still fight them. In cases, the reasons for this self-falsification may not be so hard to understand. A maimed soldier may "know," but still formally deny, that lies brought him to Iraq, lest the sense of betrayal crush him. If one had few life chances, commitment to "values" might be especially important, functionally vanishing one's knowledge of their manipulation for others' gain. But the incentive for wearing the mask does not ultimately matter in Sloterdijk's model. The point is that the mask is chosen, for whatever reason, and cynical reason may not be rational from the standpoint of its subjects. (At an extreme of dissonance, the "knowing" subject might himself fabricate the mask, as in the fallacy of an Iraq-9-11 link.) Cynical reason appears a more perfect form of power because perfectly immunized against charges of deception. Ideology critique becomes futile when there is no hidden truth to reveal. Additionally, power itself becomes more deeply cynical when it no longer requires that we accept its lies, even if it keeps presenting them. (Absent any official rationale, there would be no ideology, and power would be fully cynical.) What opponent of the Iraq war could not relate to the paralysis or even terror of the following, far from unimaginable, scenario: making the case to a Bush defender that the war was never about preemption or liberation, that it's goal all along was to demonstrate American power, and him responding simply, "Of course. So?"

However compelling, "cynical reason" does not wash as a comprehensive account of American derangement, as it assumes a situation of total transparency. Clearly, there remain instances of genuine ignorance and deception worthy of a political response. The concept's utility is as a kind of thought experiment pointing to new possibilities: in this case, that many Bush supporters may, in effect, already see through him, such that we are dealing with a new strain of ideology resistant even to a fortified politics of persuasion. It has additional value in generating, as Zizek's foil, a final model of ideology.

Sloterdijk contends that in the West we are now, in essence, "post-ideological" societies, and that this is ultimately liberating. If power is absolved of duplicity, so too is the public — wise to the ideological ploy-free from deception. The freedom is experienced in a cynical distance from the manipulative message. This can be readily seen in the now familiar relationship between consumer and advertiser, in which both parties know that the ad is a kind of fantasy or false promise; that it offers only a soft drink, or cell phone, or athletic shoe, and that these things cannot provide in themselves the joy or love or courage being shown. (A whole genre of advertising as parody lays bare its own alluring codes.) This mutual, often playful understanding of the rules of the ideological game very much defines "postmodern irony"-a sensibility that became in the 1980s the dominant cultural trope, suffusing advertising, entertainment, and the media. It could characterize as well a new cynicism about politics: the pervasive sense that of course politicians lie, that there's naturally a difference between their image and their true selves, their stated and their real motives. [30] From the other side, the skill of politics lies in fabricating a compelling image of authenticity, even if the public knows it's just an image. The "liberation" comes in peoples' odd sense of empowerment, despite their cynicism, in not being fooled. I recall a man telling me during the 1991 Gulf War, with palpable satisfaction at his insight, that the real reason for the conflict was that "Our boys in the military wanted to try out all their new toys," like Patriot Missiles and "smart" bombs. Acknowledging the deception, he nonetheless supported the war.

Against Sloterdijk, Zizek declares this ostensibly post-ideological liberation false by asserting that ideology lies not on the side of knowing, but of doing. To explain, he rehearses how Marx extracted, without quite realizing it, the idea of constitutive misrecognition from his analysis of the commodity form. According to Marx, the commodity system is predicated on an illusion, as incommensurable qualities (use-values) are exchanged as quantitative equivalences (exchange-values). The system is organized around money as a pure form of exchange value bearing no intrinsic worth (especially when in paper form). Whatever insights participants in commodity exchange might make into this abstraction, they sustain the illusion of equivalence in practice, in the act of commodity exchange itself. 
For Zizek, ideology refers to the whole mechanism whereby the role of illusion in constituting social "reality" itself is obscured:

"Ideological" is not the "false consciousness" of a (social) being but this being itself insofar as it is supported by "false consciousness," ... not [an] illusion masking the real state of things, but that of an (unconscious) fantasy structuring our social reality itself. And at this level, we are of course far from being a post-ideological society. Cynical distance is just one way ... to blind ourselves to the structuring power of ideological fantasy: even if we do not take things seriously, even if we keep an ironical distance, we are still doing them. (Zizek 1989:21,33)

Most obviously, this dense quote suggests we do not overcome ideology simply by seeing through the illusion. With respect to advertising, it does not matter whether we buy the fantasy, only that we buy the product; when we do, the illusion will have retroactively worked, even if we never quite fell under its spell. Similarly, we gain nothing by seeing through politicians if we nonetheless reward them with our support or simply admire their image-craft. Far from outsmarting the system, "ironic distance" offers the palliating illusion of no longer being tricked, while occluding the persistence of mystification; we thus fall victim to a higher form of illusion, a crueler joke.

Zizek's more complex point about the source of misrecognition warrants explication, for which returning to Baseball's steroids scandal is helpful. Baseball functions as a competitive sport only if one accepts the premise that its players are not cheating, beyond the mild, catch-me-if-you-can transgressions of scuffed balls and stolen signs. That premise is in fact the one essential article of faith; withdraw it, and there is no game. Holding on to that faith, when one knows it is being violated, amounts to a constitutive illusion, as it permits the thing itself to be. This approximates the absurdity of the last two decades, when fans could fairly well see that players were using steroids, but still avidly followed the game. [31] To extend Zizek's model, the "moment" of blinding faith does not lie in any formal renunciation of the charge of steroid use or equivocation about it (no perfect proof yet exists, perhaps it's only a few players, etc.). Rather, it occurs when actively participating in baseball as a fan: plunking down money for a game, but even just thrilling to the drama of a pennant race. Only through these acts, predicated on an illusion fans may even not hold, does baseball reproduce itself. And in the case of baseball, uniquely concerned among sports with tradition and history, removing the problem would not expel the illusion. For even if the game were now totally clean, the achievements of steroids-era players can be enshrined in the statistical-historical record only through acts of forgetting.

Having made Zizek's analytical matrix more vivid, it is now time to apply it to American politics. What might be the United States' "social being" and the "fantasy" or "illusion" constituting it? What are the implications of the answers we provide? Before providing them, a small caution: highly abstract concepts such as these may map imperfectly onto our topics; we therefore aim only for a rough, mutually illuminating correspondence between theory and its objects.

My contention here is that America's "social being," defined as its dominant or fundamental identity, is today “empire." I make as yet no judgment as to the morality of empire, only recognize that America projects its power on vast scale. The sustaining illusion of its people-the essential ideology of empire-is that America deserves to be one. That is, the country's status as preeminent world power results from America having some special talent, resourcefulness, store of virtue, or divine mandate that rightly sets it apart from and above other nations. A circularity defines the whole thought: we are an empire because we are supposed to be.

While perhaps not universal, this belief is, I think, absolutely pervasive among Americans. It is certainly held by conservatives like Bush, whose framing of America's global profile oozes with reference to the country's special moral destiny. To be fair, Bush does not claim that the United States has unique possession of the core virtue of liberty. With perfect Lockean idealism, he insists that liberty is the universal gift of "the Almighty," but that America has a special power and duty to bring it to the world. The ideological claim becomes "false" or an "illusion" when the conduct of empire plainly contradicts the virtue being claimed. This has been the case, above all, in the torture at Abu Ghraib, which savagely deprives the tortured of freedom over his own body (the essential "natural right," according to Locke). The stubbornness of the illusion was evident as Bush thundered on the campaign trail that "torture is un-American!" and that the world will see how true this is when we punish the small handful of culprits. The whole affair seemed for him less an occasion for shame and an exhaustive inquiry into a likely systemic problem than an opportunity to assert, in near jingoistic tones, the depth of American virtue. (Needless to say, the punishments so far have been sparse and slight.) Likewise, the administration's offense at the Amnesty report was not over the U.S. 
conduct the report questioned, but instead that Amnesty International had denied America its desired moral statusrhetorically stripped the naked emperor of his imaginary clothes.

Liberals may wish that America assert its power more circumspectly, but do not typically deny it a special status. Some liberal thinkers, notably Michael Ignatieff, asked if America should proudly claim the title of empire and brazenly use its might to liberate the world. [32] Even leftists loudly condemning the gap between American rhetoric and conduct may yet assume the basic legitimacy of America's elevated global status. And whether or not he would have led us into war in Iraq in the first place, Kerry promised-with an irony his supporters downplayed-to basically stay the course of Bush's policies. (A modest revision was greater involvement of Europe in post-invasion Iraq; to tempt the erstwhile imperialists in, he proposed appealing to their geo-strategic stake in regional stability and economic interest in reconstruction profits). Moreover, Kerry failed to do with respect to the Iraq war-lest Americans disdain the message and the messenger-what he courageously did with respect to the Vietnam War: speak out against the atrocities committed in the name of virtue and the profound moral contradictions they create.

But whatever the strength and breadth of the illusion, empire ultimately is as empire does. This simple phrase, which combines Zizek's mind-bending theorems with the homespun wisdom of Forrest Gump's mother, has important consequences. (When Forrest complained that the world regarded him as a half-wit, she would reply lovingly "Stupid is as stupid does," such that what matters in not the perception but the conduct.) From Zizek's perspective first: it is not so much that America's special virtue produces its imperial power; rather, the power itself presupposes the ideology of American virtue. Further, by the very reality of this power, the ideological fantasy holds, even if the virtue is violated and even if Americans, recognizing this, were to formally renounce belief in it. There seems, in other words, no point at which you may simply "know too much" about power for it to survive, because the fantasy follows from the social reality it at the same time creates. [33] (By way of analogy, the collective, simultaneous realization that money is only worthless paper would not, in itself, dissolve the commodity system. The collapse would occur only if people actually stopped trading goods and services for what are, after all, worthless pieces of paper.)

What this suggests is that it does not matter so much how we feel about being an empire, whether we think we live up to our ideals, and so on, but only that we are an empire. In a nearly violent oscillation, the emphasis regarding ideology thus shifts from discourse back to practice, from thought to action, and from the derangement of the right to the weak and often misplaced activism of the left. What America needs is to stop being an empire, and this requires less a new lens to correct reality's distortion or an attitude adjustment than, as a nation, massive behavior modification. The obverse of the iconic Nike slogan, "Just Don't Do It," becomes a plausible Zizekian credo with respect to empire, summoning the spirit of Marcuse's Great Refusal, even if the goals may be less ambitious.

For inspiration and practical guidance, enter Forrest Gump's mother, whose revised maxim might counsel that if we no longer want to be an empire, we have to stop the practices of empire. Common sense dictates that one start where the offense is greatest, the symbolism the richest, and one's case the strongest. For four years now, the detention facilities at Guantanamo Bay-widely condemned as a "legal black hole," where uncharged prisoners can scarcely plead their innocence to prevent lifetimes of detention-has represented the existential negation of bedrock principles, like the rule of law and basic respect for human liberty, in whose name the "war on terror" is purportedly waged. With the recently reported desecration of Korans in the prison, freedom of worship is also assaulted. Editorials and legal briefs have accomplished little in diminishing the shame of Guantanamo. It may therefore be time to heed the recent call of Senator Robert Byrd and others and build a broad public campaign to at last shut the prison down. [34]

Empire also has its structural predicates, and here the task may be oddly easier. Whether or not primarily motivated by the desire for oil, the Iraq invasion and broader Middle East morass are clearly connected to the dependence of "our way of life" on fossil fuels. ("We wouldn't attack Iraq if all Kuwait had was broccoli," protesters would say of the first Gulf War; the same logic today holds.) [35] Hence, changing our way of life by curing the SUV addiction, shifting to renewable energy sources, expanding public transit, and disciplining our use of electricity become vital. Pursuing these goals, which save money and the environment both, represent strikes against empire that do not so directly challenge patriotic passion or pick at the still-throbbing wound of September 11. As added appeal, they represent ways of beating Bush, so to speak, without beating Bush.

The list of desired, practical changes could be endless, and accomplishing any of them of course requires convincing people of the value of doing so. Engaging the battle for hearts and minds, no matter the slings and arrows of outrageous quiescence and ideological distortion, is therefore unavoidable; it remains, moreover, the 
crucial requirement for democratic action. Finally, part of the healing requires that the America, like a psychotic deluded by false grandeur, relinquish the conceit of its own uncorrupted virtue. The United States, like all nations, should be more moral, and achieving this is best done without the fantastical sense-no matter genocide, slavery, Hiroshima, and torture-that we already are the most moral nation, now or ever. Protestations of moral purity, as in Bush's smugly righteous response to Abu Ghraib, serve too often as cover for or even impetus to moral blight. Even so, when addressing one's fellow citizens, it may not be possible to escape entirely this fantasy (and it would be anyhow absurd to hold that America is only an empire, its store of virtue nearly drained). All forms of ideology, for that matter, have stubborn lives. And when the work seems too difficult, the minds too far gone and the hearts too hard, it may be time for the solace of some earthy, American pleasure that gives again a sense of hope, like a blues concert or an afternoon of baseball.

The Yankees are in big trouble this season, but the Mets are fun to watch. Want to go see a game?

\section{Endnotes}

1. Robin Palmer, interview with author, November 11, 1994.

2. "McGwire mum on steroids in hearing," March 17, 2005, at http://www.cnn.com/2005/ ALLPOLITICS/03/17/steroids.baseball/

3. As of May 17, 2005, only two people, both hands-on torturers, have been convicted of crimes at Abu Ghraib, and six codefendants have entered into plea agreements. "Soldier is Found Guilty in Abu Ghraib Abuse," New York Times, May 17, 2005, p. A9. On the precedent for and extent of abuse at the prison, see Greenberg, Karen J. and Joshua L. Dratel, eds. 2005. The Torture Papers: The Road to Abu Ghraib. New York: Cambridge University Press. To date, baseball's modestly revamped steroids policy has netted only a handful of marginal, mostly Latin-American players. The recent corporate scandals have resulted in some high-profile convictions, but none yet among Enron executives.

4. The U.S. bombing of Afghanistan began on October 7, 2001. Professor Marc Herold, drawing on NGO, newspaper, and wire service reports, estimated that by December as many as 2,970 Afghan civilians had been killed by U.S. bombs; by July 2002, he put the figure as high as 3,620. "Attempts to Hide the Number of Afghan Civilians Killed By U.S. Bombs Are an Affront to Justice," The Guardian, August 8, 2002.

5. "U.S. Behind Secret Transfer of Terror Suspects," Washington Post, March 11, 2002, A1.

6. This characterization is supported by the detailed study of University of Maryland professor Susan D. Moeller, "Media Coverage of Weapons of Mass Destruction," Center for International and Security Studies at Maryland, March 9, 2004, found at http:// www.pbs.org/newshour/bb/media/jan-june04/ nytimes_05-26.html.

7. The Times detailed and offered explanation for many of its errors in its May 26, 2004 issue.

8. This misperception will be discussed below and referenced in a subsequent footnote.

9. The language of deliberately "fixing" intelligence comes from a hitherto secret British memo, published by The London Times on May 1, 2005, reporting on a meeting of high-ranking American and British officials eight months before the U.S. attack. The memo, whose revelation played a role in the Labor Party's poor showing in the May 2005 elections, added additional support for a thesis regarding the manipulation of intelligence long held by American critics: Danner, Mark. 2005. "Secret Way to War: The British SmokingGun Memo." The New York Review of Books, June 9, also at http://www.tomdispatch.com/index. mhtml?pid=2486.

10. In the wake of the revelation that "Deep Throat" was the FBI's Mark Felt, editorialist Bob Herbert called on Congress, the press, and the American people to hold George Bush to account, as they finally did with Nixon. See Herbert, Bob. 2005. "Truth and Deceit." New York Times, June 2.

11. Barstow, David,William J. Broad, and Jeff Girth. 2004. "How White House Embraced Suspect Iraq Arms Intelligence.” New York Times, October 3.

12. Bob Herbert appropriately asked in early 2005 , "As a nation, does the United States have a conscience? Or is anything and everything $\mathrm{OK}$ in post-9/11 America? If torture and the denial of due process are $\mathrm{OK}$, why not murder? When the government can make people just vanish-which it can and which it does-where is the 
line that we, as a nation, dare not cross?" "It's Called Torture," New York Times, February 28, 2005, p. A19.

13. On the Billionaires for Bush, see Haugerud, Angelique. 2004. "The Art of Protest." Anthropology News, November, vol. 45(7) and "Leave No Billionaire Behind': Political Dissent as Performance Parody," Princeton Report on Knowledge, vol. 1(1), 2005, at http://www.princeton.edu/ prok/inventions.hmtl.

14. The quote is from counterculture author Paul Goodman in 1967, found in my Bringing the War Home: The Weather Underground, the Red Army Faction, and Revolutionary Violence in the Sixties and Seventies. Berkeley: University of California Press, 2004:137. Generalizing about the antiwar movement is of course difficult. Some radicals, notably the Weathermen, had periods of doubt as to the will of the American people regarding the war, leading them to ask whether they were ultimately fighting on behalf of, or against, the American masses. For a discussion of this tension, and the larger question of the public's attitude toward the war, see the chapter "'Hearts and Minds': The Antiwar Movement, Violence, and the Critical Mass."

15. This is Slavoj Zizek's characterization of the classic view of ideology, contained in "How Did Marx Invent the Symptom?" The Sublime Object of Ideology. New York: Verso, 1989:28.

16. This was the broad thesis of Zizek's short essay "Welcome to the Desert of the Real," written on September 15, 2001, and which flew around the internet. A version is at http://web.mit.edu/cms/ reconstructions/interpretations/desertreal.html. Zizek expanded and substantially modified the thesis in Welcome to the Desert of the Real: Five Essays on September 11 and Related Dates. New York: Verso, 2002.

17. Marcuse developed this analysis most clearly in Herbert Marcuse. 1964. One-Dimensional Man: Studies in the Ideology of Advanced Industrial Society. Boston: Beacon Press, where he introduced the concept of the Great Refusal.

18. This assumption is shared less by highly partisan media like Fox News, which routinely editorializes as it reports, and by figures like CNN's Lou Dobbs, who uses his nightly program as a platform for relentless criticism of U.S. immigration and trade policy.

19. "Happy Captives" is the title of the book's eighth chapter.

20. Rick Perlstein, whose blurb calls Frank's book "the true story of how conservatives punk'd a nation," has laid out a detailed argument as to how and why the Democrats could succeed with a platform of economic populism in future elections. "How the Can the Democrats Win," Boston Review at http://www. bostonreview.net/BR29.3/perlstein.html.
21. Identifying lapses in the Democrats' image-craft is the near-exclusive focus of Frank's recent essay "What's the Matter with Liberals?" New York Review of Books, May 12, 2005.

22. For an ingenious theorization of the Billionaires for Bush and other forms of cultural activism, see Andrew Boyd and Stephen Duncombe, "Manufacturing Dissent: What the Left Can Learn from Las Vegas," Journal of Aesthetics and Protest, volume 1, \#3, 2004. Boyd and Duncombe address many of the themes of this essay-chiefly the apparent paralysis of resistance politics when "truth" no longer seems to matter-with an exhilaratingly fresh perspective. Rather than mourn the abuse of reality, they counsel that progressives themselves fabricate compelling versions of it by creating their own myths and spectacles.

23. "Senator Clinton Assails G.O.P. at Fundraiser," New York Times, June 7, 2001, pp. B1, B4.

24. "Hussein Link to 9/11 Lingers in Many Minds," Washington Post, September 6, 2003, p. A1.

25. "Bush: No Link Between Iraq, Sept. 11 Attacks," Fox News, September 17, 2003, at http://www.foxnews. com/story/0,2933,97527,00.html.

26. The Harris Poll ${ }^{\circledR} \# 14$, February 18, 2005 at http://www.harrisinteractive.com/harris_poll/index. asp?PID $=544$.

27. I make no claim here as to the accuracy of these frames. Zizek introduces his post-9-11 essays by asserting that the least democratic aspect of the "war on terror" is the coercive and reductive assumption that the only two possibilities are democracy of the American sort and "fundamentalism" of the radical Islamist sort. Welcome to the Desert of the Real, 1-3. The Islamist challenge seems to me illiberal and antimodern in deeply pejorative senses.

28. "Rights Group Defends Chastising of U.S.", New York Times, June 4, 2005, p. A5.

29. The gentleman's real name is Jeff Guckert, and his only credentials were as a self-described journalist working for a brazenly partisan website.

30. Whether this is more a legacy of "Tricky Dick" or "Slick Willy" the lies of Vietnam and Watergate or of the Clinton-Lewinsky-Starr affair, is a matter of political taste. For the argument that Nixon was the great pioneer of image-craft in American politics, see Greenberg, David. 2003. Nixon's Shadow: The History of an Image. New York: W.W. Norton and Company.

31. The chase of Mark McGwire and Sammy Sosa, both suspected steroid users, of Roger Marris's home run record is widely credited with reviving baseball after the 1994 strike.

32. See especially, Ignatieff, Michael. 2004. "Lesser 
Evils: What Will it Cost Us to Succeed in the War on Terror." The New York Times Magazine, May 2.

33. Here I think the spirit of Zizek's text defies its letter. Zizek holds that ideology broadly "works" insofar as its determinate logic evades our recognition, and that we can therefore "know too much." But by his own logic, merely understanding how "non-knowledge" or "misrecognition" constitutes a system does not, in itself, disrupt the system's operation.

34. Senator Byrd introduced in April 2005 an amendment to stop funding, and hence shut down, U.S. detention facilities in Guantanamo Bay. The amendment was to the Emergency Supplemental Appropriations Act for Defense, the Global War on Terror, and Tsunami Relief, 2005, and would have eliminated \$36 million for construction of a permanent military prison there. The more influential but less courageous Senator Joseph Biden recently echoed Byrd's call to close the prison, though primarily to deny our enemy its "greatest propaganda tool." "Biden Says Prison at Guantanamo Bay Should be Shut Down," Washington Post, June 6, 2005, p. A02.

35. President George Bush, Sr., who led the first Gulf War, had a notorious dislike of broccoli.

\section{References}

Barstow, David, William J. Broad, and Jeff Girth. 2004. "How White House Embraced Suspect Iraq Arms Intelligence." New York Times, October 3.

Bissinger, Buzz. 2005. "Home Runs Wanted. No Questions Asked.” New York Times, May 5.

Clarke, Richard A. 2004. Against All Enemies: Inside America’s War on Terror. New York: Free Press.

Dean, John W. 2004. Worse Than Watergate The Secret Presidency of George W. Bush. New York: Little, Brown.

Frank, Thomas. 2004. What's the Matter with Kansas? How Conservatives Won the Hearts of America. New York: Metropolitan Books.

Greenberg, David. 2003. Nixon's Shadow: The History of an Image. New York: W.W. Norton and Company.

Greenberg, Karen J. and Joshua L. Dratel, eds. 2005. The Torture Papers: The Road to Abu Ghraib. New York: Cambridge University Press.

Hersh, Seymour M. 2004. Chain of Command: The Road from 9/11 to Abu Ghraib. New York: Harper Collins Publishers.
Lyotard, Jean-Francois. [1979], 1993. The Postmodern Condition: A Report on the Status of Knowledge. Translated by Geoff Bennington and Brian Massumi. Minnesota: The University of Minnesota Press.

Marcuse, Herbert. 1964. One-Dimensional Man: Studies in the Ideology of Advanced Industrial Society. Boston: Beacon Press. Miller, Matt. 2005. “Is Persuasion Dead?” New York Times, June 4.

Perlstein, Rick. 2004. "How the Can the Democrats Win." Boston Review. http://www.bostonreview.net/BR29.3/perlstein.html.

Rich, Frank. 2005. “The White House Stages Its Own 'Daily Show," New York Times, February 20.

Smith, Neil. 2005. The Endgame of Globalization. New York: Routledge.

Zizek, Slavoj. 1989. The Sublime Object of Ideology. New York, Verso.

-----. 2002. Welcome to the Desert of the Real: Five Essays on September 11 and Related Dates. New York: Verso. 